\title{
URBAN REALM AND TEMPLE CONSTRUCTION OF THE RUSSIAN ORTHODOX CHURCH ON THE CUSP OF 19TH AND 20TH CENTURIES (BASED ON PHOTOGRAPHIC DOCUMENTS OF KOSTANAY CITY)
}

\author{
Нурбаев Ж.Е., Нурбаева С.Б. \\ ГОРОДСКАЯ СРЕДА И ХРАМОВОЕ СТРОИТЕЛЬСТВО РУССКОЙ \\ ПРАВОСЛАВНОЙ ЦЕРКВИ НА РУБЕЖЕ ХІХ-ХХ вв. \\ (по материалам фотодокументов города Костанай)
}

\begin{abstract}
The article is devoted to considering "church construction" on the territory of Kostanay city, which broadly speaking includes building of churches, church government, and administrative organization. The investigations have led to a conclusion that the main factors contributing to soaring church construction in rapidly growing Kostanay city on the cusp of $19^{\text {th }}$ and $20^{\text {th }}$ centuries were active migration processes resulting in movement of significant number of orthodox people from European part of Russia, as well as development of missionary activities among native population. On the basis of photographic documents, the authors have characterized orthodox temple architecture, as well as subdivided churches according to "institutional principle", composition and spatial dynamics, and style of space-planning decisions. It was found that a greater number of churches in Kostanay were the parish ones, prayer halls of temples had a single or five-domed top, the following architectural styles were distinguished in the temple construction: eclecticism, elements and techniques of provincial Baroque and classicism, national Russian style combined with the techniques of the "brick" style. Within church construction, the government was tasked with designing living environment in general, rather than religious buildings. The urban realm balanced all aspects of confessional life, included its physical, functional_ pragmatic, social, as well as emotional and artistic parameters. After Orthodox temples were built and given certain functions, there were changes in the social structure of the society, the parish was growing, the number of priests was increasing, which led to changes in the urban realm. The environment is connected with
\end{abstract}

Аннотация. В статье рассматривается «церковное строительство» на территории города Костанай, понятие, которое в широком смысле включает в себя собственно строительство церквей, церковное управление, административное деление. Статья направлена на выявление факторов и особенностей церковного строительства в г. Костанай и его влияние на развитие городской среды, анализ и выявление основных закономерностей и типологических особенностей архитектурно-планировочной организации православных храмов. Сделан вывод о том, что главными предпосылками стремительного церковного строительства в быстро растущем городе Костанай на рубеже XIX-XX веков являлись активные миграционные процессы, переселение из европейской части России большого количества православного населения, a также развитие миссионерской деятельности среди коренного населения. На основе фотодокументов дается характеристика храмовому православному зодчеству, производится деление церквей по «ведомственному принципу», по композиционно-пространственному аспекту и по стилистике объемно-планировочного решения. Было определено, что большее количество церквей города Костанай были приходскими, молитвенные залы храмов имели одно- или пятикупольное завершение, в храмовом строительстве были выделены следующие архитектурные стили: эклектика, элементы и приемы провинциального барокко, классицизма и модерна, национальный русский в сочетании с приемами «кирпичного» стиля. В условиях церковного строительства была поставлена задача проектирования не столько зданий культовых сооружений, сколько среды обитания в целом. Городская среда гармонично связывала все аспекты конфессиональной жизни, включала материально-физические, функциональнопрагматические, социальные и эмоциональнохудожественные ее параметры. Вслед за строительством православных храмов, насыщением их функционалом, происходили изменения в социальной структуре общества, увеличивался приход, расширялся штат священников, что приводило к переменам и в городской 
the main elements of the urban system, having stability and variability, respectively, which resulted in a set of individual and collective creative acts. The Russian Orthodox Church had a great influence on education and the moral state of urban dwellers. A network of parochial schools was formed at each church and each temple. Such schools pursued not only educational, but also missionary goals.

Keywords: Kostanay, urban environment, photographic documents, Russian Orthodox Church, church (temple) construction, diocese, cathedral, monastery, architectural styles.

About the author: Nurbayev Zhaslan Yesseyevich, ORCID: 0000-0003-48626152, Ph.D., L.N. Gumilyov Eurasian National University, Nur-Sultan, Kazakhstan, nur1282@mail.ru; Nurbayeva Sailaugul Bauyrzhanovna, A. Baitursynov Kostanay Regional University, Kostanay, Kazakhstan; salli_1984@mail.ru среде. Среда связана с основными элементами городской системы, которые обладали устойчивостью и изменчивостью соответственно, что выражается совокупностью индивидуальных и коллективных творческих актов. Большое влияние русская православная церковь оказывала на сферы образования и нравственное состояние горожан. При каждой церкви и каждом храме создавалась сеть церковно-приходских школ. Такие школы преследовали не только просветительские, но и миссионерские цели.

Ключевые слова: Костанай, городская среда, фотодокументы, русская православная церковь, церковное (храмовое) строительство, епархия, собор, монастырь, архитектурные стили.

Сведения об авторах: Нурбаев Жаслан Есеевич, ORCID: 0000-0003-4862-6152, канд. ист. наук, Евразийский национальный университет имени Л.Н. Гумилева, г. Нур-Султан, Казахстан, nur1282@mail.ru; Нурбаева Сайлаугул Бауыржановна, Костанайский региональный университет имени А. Байтурсынова, г. Костанай, Казахстан, salli_1984@mail.ru

\section{Introduction}

Evolution of the environment is an irreversible phenomenon in historical cities with architectural monuments of different periods. A small settlement of Kostanay has grown up into a large commercial and industrial regional center, which is a bearer of the multinational culture. The modern urban environment reflects historical, socio-economic, political, and cultural traditions characteristic of this region, which has been developing over several centuries.

At the present stage, in the Kazakhstani society, as well as worldwide, formation of a harmonious urban environment and adaptation of historical and architectural heritage to the modern requirements of life have become of utmost importance. The modern construction boom in Kazakhstan has set the task of designing not so much separate buildings, but the environment as a whole, harmoniously linking all its physical, functional, pragmatic, emotional, and artistic parameters.

In search of reference points for this construction, it was expectedly turned to prerevolutionary history, history of religion and temple architecture. It has paved the way for the process of returning the lost values, i.e. restoration of the destroyed churches, reconstruction and transfer to religious organizations of the preserved ones, as well as construction of new temples of various religious affiliations. After gaining independence, Kazakhstan has begun construction of both Muslim and other religious temples, including Orthodox ones, since after Islam, Orthodoxy is the second largest religion in the Republic.

The work is aimed to specify factors and peculiarities of church construction in Kostanay city and its impact on the development of urban environment, as well as to identify and to analyze the principal patterns and typological features of the architectural and planning organization of Orthodox churches. 
The research methods include use of pre-revolutionary and contemporary literary sources, periodicals and research works related to this topic, as well as collection and processing of project and photographic documents, graphic materials, archive and museum funds. The topic is an interdisciplinary one; therefore, the methods of related fields have been applied in investigating it, i.e. environmental approach, architectural analysis, historical, typological, and comparative, etc.

Historiography. The topic is of interdisciplinary nature. Material life of a city is investigated in many sciences. The same concerns its spiritual life and its certain aspects.

Taking into account multidimensional and ambivalent character of urban realm phenomenon, the authors have considered works of philosophers, sociologists, cultural experts M. Weber, U. Eco, F. Brodel [1].

A great assistance in defining architectural forms and styles was rendered by research of Russian architects. For example, Ye.A. Feoktistova considers the evolution of the city-planning culture of Kazakhstan [2], Z.V. Popova studies Orthodox architecture [3], and P.V. Mikhnova investigates the urban realm and the architectural and artistic system of historical cities of NorthEastern Kazakhstan [4]. The research of Archpriest Alexander Bertash and the collective work of Ye.R. Voznyak, V.S. Goryunov, S.V. Sementsov are also of certain interest [5].

In Kazakhstan, articles devoted to peculiarities of formation of urban space in the Modern Age are gradually appearing. Using the example of the cities of Semipalatinsk and UstKamenogorsk, G.A. Sarsembayeva conducts an analysis of ethnic and social evolutions in the structure of the urban population, shows the transformation of the urban image [6].

G.A. Alpyspaeva, Sh.N. Sayakhimova investigate the role of merchants in the development of the city of Akmolinsk, including their contribution to the construction of religious buildings in the provincial city [7].

An important and unique sources of information are local history literature, literature dedicated to the history of the city of Kostanay. It is necessary to mention here the research of Kostanay historians I.K. Ternovoy, Ya.K. Dukhin, and others, who wrote both collective anthologies, fundamental monographs, and individual articles in local newspapers and journals [8].

Changes in the ethnic confessional structure of the population of the Kostanay region. In the second half of the $19^{\text {th }}$ - early $20^{\text {th }}$ centuries, land relations in the European part of Russia became strained, and the tsarist government, in a bid to preserve the landlord property rights in the central part, made an attempt to sort out agrarian conflicts by state incentives for resettling peasants from the populated south-western and central provinces to the remote south-eastern areas of the Empire. As a result, the ethnic characteristics of Kazakhstan was radically changed, there was a dramatic spike in proportion of the Slavic component, and hence, there were changes in the confessional structure towards increase in the number of the Orthodox population.

The growth of the Orthodox Faithful was recorded in the annual statistical reports. Between 1900 to 1911, there was a progressive growth of the Orthodox population, especially in Kostanay uyezd. In 1899, 18431 Orthodox Christians lived here; in 1911, their number made 147527 people. In Kostanay city in 1899 there were 14445 Orthodox Christians, in 1911 this number doubled to 22,596 people [9]. Let us consider the confessional structure of the population in accordance with 
the First General Population Census of the Russian Empire in 1897 in a more detailed way. For instance, the census survey demonstrated that the proportion of Orthodox Christians in the Turgay region was $8.2 \%$ of the total population. For example, there were 170 Old Believers and dissenters, of whom the majority lived in Kostanay uyezd [10].

Organization of administering Orthodox parishes. These processes determined institutional structuration of Russian Orthodox Church on the territory of Turgay region. The second half of $19^{\text {th }}$ century gave the start to mass construction of Orthodox churches. In 1869, in Moscow a special organization - "Missionary Society" as well as missionary camps and posts were founded to carry out the task of "Christian education of the native population". By a special government decree, it was proposed to punish people convicted of propagating unorthodoxy among the Orthodox with imprisonment in the fortress. However, adoption of Orthodoxy by the Unorthodox was given the utmost encouragement. The government demanded that its representatives on the ground systematically inform on the situation with faith in the province and the measures taken to bolster the influence of Orthodoxy.

The territory of the modern Kostanay region was governed by the Orenburg Diocese, which was established in 1799. Before the Orenburg Diocese was formed, the territories that made it up had been under jurisdiction of the Kazan and Tobolsk Dioceses. In 1859, the Holy Synod formed two independent dioceses - Ufa and Orenburg-Ural ones. Due to active migration wave of the late $19^{\text {th }}$ - early $20^{\text {th }}$ centuries, the government of the diocese was made to establish two vicariates - in Uralsk and Chelyabinsk. September 10, 1908, the Chelyabinsk Vicariate was formed by the decree of the Holy Synod. November 13, 1914, within the Orenburg Diocese, a second vicariate - the Kostanay one - was established.

Findings. Due to the large influx of back-settlers, the number of churches and parishes in Kazakhstan more than doubled. After having arrived in the northern regions and halfway got settled in their houses, the immigrants immediately raised the question of building a parish church for them. Since the very beginning, they paid attention to the distance from the church, for they used to live near churches when being in Russia, and therefore, a long distance from the church was highly undesirable for them.

From 1859 to 1915 , the number of churches in the Orenburg Diocese increased almost fourfold. Almost all the churches in the Orenburg governorate were built at private expense. For construction and decoration of churches and monasteries, the Synod and consistories allowed fundraising in the province or in the country.

The first project of the Russian Orthodox Church in the territory of Kostanay city was a wooden chapel in the name of Nikolay Chudotvorets. Pavel Podbelsky was appointed the first priest, who was sent to Troitsk city constructed in the Kostanay tract from the Grado-Troitskiy Cathedral [11, p. 50]. However, he paid flying visits to Kostanay, and the priest Vasily Gilyarov, whose name is associated with many charitable events in the city, permanently ministered at the chapel built [12, p. 160]. In an archival document dated 1882 it is indicated that when designing the chapel, a special place was already allocated for the construction of the church [11, p. 50]. 
The very first Orthodox church in Kostanay was the small Nikolsk Church, which was located in the center of the city (the territory of the modern Central Park). Due to the rapid growth of the city and increase in the population, one church could not cater to all the religious needs of the townspeople. Therefore, in 1886, it was decided to build a new, more spacious church.

In 1887, the wooden Michael the Archangel Church was founded, which was decided to be built on the outskirts, between the town and Konstantinovich village (territory of the modern Central market). The new church was built two years later on donations raised in the amount of 13 000 rubles thanks to the collections of both residents of the city and representatives of all regions of the Empire. For beauty and popularity among the prominent citizens of the Archistratigus Michael's Church was called the "merchant" one.

At that time, drunkenness was a social problem of paramount importance to the urban population. Both the city authorities and the Orthodox clergy were worried about this. Thus, the city judges petitioned the city Duma to take the most drastic measures against drunkenness, as well as for making drunk people undergo appropriate punishment [13, pp. 17-18]. At the beginning of the $20^{\text {th }}$ century, the activities of religious organizations under the Michael Archangel Church were of particular importance. The largest of them was the Kostanay Temperance Association, which was engaged in educational and religious propaganda [14, p. 44].
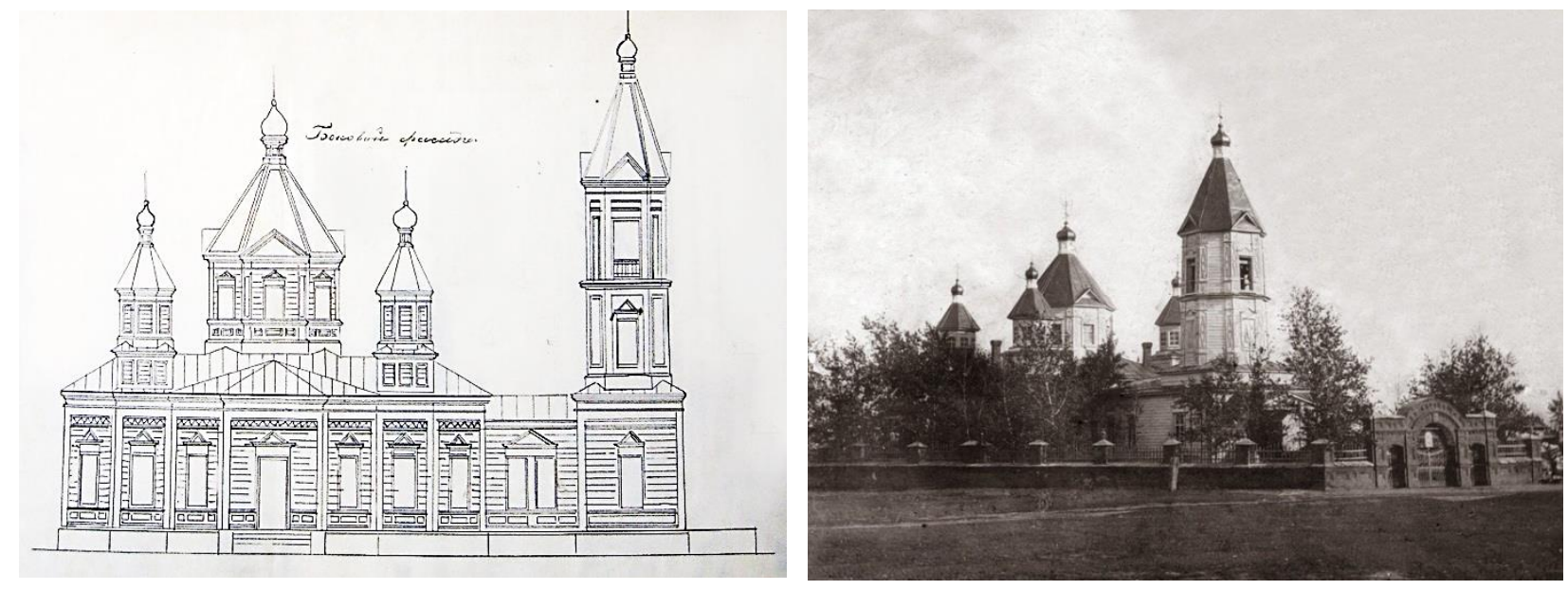

Photo 1. Construction plan and photo of the Michael Archangel Church of the early twentieth century [15]

The historical photo of Michael Archangel Church, preserved in the Kostanay Regional Museum of Local History, as well as the project plan of the Church, found in the Central State Museum of Kazakhstan enable to characterize its style, and architectural features.

The wooden church named after Archangel Michael had a size of 19 x 18 meters (or 9 x 8.5 sazhens) and was built without a single nail. The church was a unique object of the tent style in architecture. The tent style is an architectural design in the form of a multi-faceted pyramid completing the structure. The tent design in Russian architecture replaced the domes in wooden construction. In wooden buildings, unlike the stone ones, it is extremely difficult to convey the shape of the dome, the design of the tent is much simpler. It was the tents that gave the buildings a 
magnificent pillar-like silhouette. Thus, the wooden temples displayed for the world in the form of a huge pointed wooden cone

The life of an Orthodox church is a continuous process of development and changes. One cannot consider a temple as a completed project, for it is developing and living together with the community. Creating a new church begins with the allocation of the community of the future parish, which is able to raise money for construction of the church and support the parish and the church itself in the future. After construction of the church is completed, chapels, a bell tower, parish houses, a church school, etc. are gradually appearing around it. From a small church, large cathedrals may grow. So, near the small wooden Nikolsk Church, the majestic stone Nikolsk Cathedral was built in the late $19^{\text {th }}$ century.

The first mention of the intention to build a cathedral in Kostanay dates back to 1883, when, in response to the petition of its residents, the Ministry of Internal Affairs informed the military governor of the Turgay region that "The Emperor, for humbly the report of the Minister of Internal Affairs on the $10^{\text {th }}$ day of November, has most graciously deigned to launch throughout the Empire voluntary donations for the construction in the newly founded Kostanay town area, at the Tobol river of a Cathedral in the name of St. Nicholas, according to the plan blessed by the Bishop of Orenburg and Ural" [16, p. 6].

The idea of building a temple was primarily determined by missionary goals. It can be confirmed by the circular of the military governor: "Construction of an Orthodox church among the Kazakh population will help win over their opinion in favour of the religion that this church will represent and, thus, will provide a significant service to missionary activity in the region, and will facilitate the most important Russian task in the region - involving Kazakhs-Mohammedans into Russian Christian citizenship" [17, pp. 302-303].

People started with some small donations, which became more regular and considerable since 1894, when an appeal to the residents of the Russian Empire was published on behalf of the specially founded "Committee for the Construction of the Cathedral Church" (headed by Archpriest P. Podbelsky). The whole country, even its most remote areas, took up the call. So, in spring of 1898, from the inhabitants of the Amur region, the committee received 831 rubles 24 kopecks - not a small amount of money for that time. June 6, 1898, the cathedral church was dedicated before a vast assembly [16, p. 6]. It was written in "Turgayskaya Gazeta": "Every now and again, there were crowds of curious people appearing in the streets. A lot of people flocked together from the surrounding rural areas." The consecration was performed by Bishop Vladimir of Orenburg and Ural, witnessed by the military governor of the Turgay region, Ya.F. Barabash [17, p. 303]. 

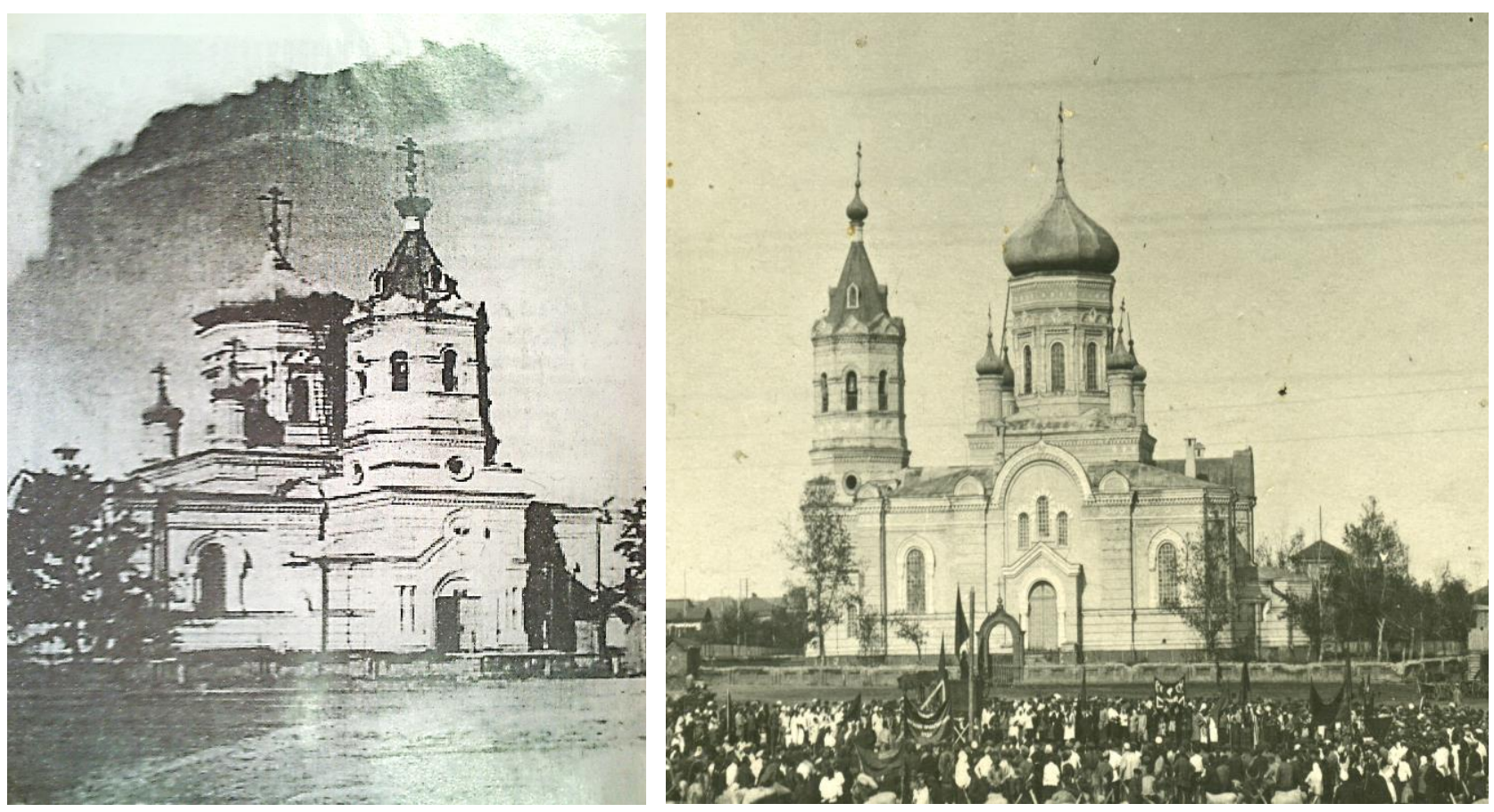

Photo 2. Nikolsk Cathedral [18]

Nikolsk Cathedral is a massive construction, the highest building in the town at that time. Its volumes and structure demonstrated the skill and experience of designers and builders. However, the name of the architect has not been found in the sources. But, there is information that Pavel Dmitriyevich Korin, a young student and successor of the famous artist M.V. Nesterov, was invited to paint the temple. Coming from the generation of icon painters of Palekh, he later became famous as the author of the grandiose idea of the painting "Rus Ukhodyaschaya" [12, p. 163].

Voluminosity of the planning solution influenced the overall verticality of the temple with the tent-shaped tops of the "bell tower" and the octagonal drum above the prayer hall, at the corners of which further four smaller decorative cupolas were installed. The building of Nikolsk Cathedral with a repressed, but expressive decoration also speaks for the knowledge and experience gained this is one of the most valuable, but lost religious buildings in Kostanay.

Nikolskiy Cathedral was meant to play a great role not only in formation and dissemination of the ideas of Orthodoxy in the region, but also in becoming a center of enlightenment and charitable initiatives, especially revealing itself in the organization of all kinds of assistance to population in distress.

In addition to parochial schools, as far back as 1884, foundation of primary male (for 30 boys) and female (for 20 girls) parochial colleges was initiated in the city [11, pp. 64-65, 68-69].

Since 1888, a single-class college opened in the city, where A. Kilyachkov, a graduate of the Kazan Teachers' Seminary, taught. In 1890, a church-school building was constructed, where 120 children, including students of a single-class college, began to study.

In 1891, the Society for the Care of Primary Education was established. City dwellers had an access to books by purchasing them in shops, and mainly through a free folk reading room, founded in 1892 at the church-school. By the early $20^{\text {th }}$ century, there were about two thousand volumes in this reading room. Here one had an opportunity to read their favourite book or to take it home for a 
while. The reading room worked under the supervision of teachers A. Kilyachkov and O. Kilyachkova [19].

In 1905, a charitable society was founded, aiming to help the poorest social ranks. Members of the society accepted donations, organized charity performances, lotteries, attended hospitals, distributed festive gifts in the orphanage, to students in need, arranged free lunches for the hungry and the restless [19, p. 138].

With the growth of the parish, the temple continued to increase, having reached its maximum size, which resulted in difficulties with performing its functions of the parish church. At this or at the previous stages, a new parish was separated from the parish and decided to build a new church. Therefore, on the cusp of the centuries, there was a need for building another temple. The Constantino-Yeleninsk Church of Kostanay was built in 1900, and consecrated May 21, 1901 by Archbishop Makariy (Orenburg).

From the second half of the $19^{\text {th }}$ century in Russia and in the Urals a growth of monasteries was in evidence, and the female monastic community significantly exceeded the number of their brethren. In 1915, there were 9 female monasteries and communities of the Orenburg Diocese out of 14; in 1913, there were 112 men who were monks and novices, and 1880 women. All the communities of monks of the Russian remote areas were entrusted, first of all, a missionary role, but there were monastic communities emerging "from below" [20, p. 20].

The rapid increase in the number of female monasteries can be explained by the following. First of all, the quality of colonization processes became different in the locations with migration flows settled. Secondly, there was a change of the demographic structure of the region's population in gender. And, thirdly, women were characterized by a higher social vulnerability compared to the men. As a result of the changed gender and age structure of the population, monasteries began to attract widows, spinsters, orphans, disabled people and other women who had fallen out of the traditional social bondings, mutual dependence relations, and failed to find an individual niche within the worldly life [21].

So, in Kostanay, simple peasant girls showed themselves willing to establish a house of prayer. Ya. K. Dukhin describes history of forming the monastery as follows: "In 1890, Right Reverend Makariy visited Kostanay. The high church rank took the concerns and needs of the nuns to heart and gave them a promise: 'Everything that only depends on me, and more than that, I will do to you.' Makariy's support was of paramount importance, and his efforts were ensued by the decree of the Holy Synod on the official foundation of the female community in Kostanay in 1894. Much later, in 1907, it was transformed into a monastery. The name was given to it in honor of the Iveron Icon of the Mother of God. By the way, on the territory of the Orenburg Diocese in those years there were only two monasteries: one of them in Kostanay, the other one in Uralsk - for men [22, p. 6].

In 1892, 25 elderly women and 3 children lived in the community, who made their living mainly by arable farming. To make this community consolidate and create, the city deputies decreed to allocate to the female community six dessiatines of land for a farmstead and for arable 
farming from the general city allotment of 250 dessiatines of state-owned land near the former hibernating area of Sultan Seydalin, from the border of the state horse breeding [11, pp. 107-109].

The first Mother Superior was Ye. Borodina (Hegumeness Anna), in 1915 Hegumeness Raphaila took over from her. In the "Overview of the Turgay Region" for 1899, it was reported about 144 "nuns" of the monastery. Secretary of the Orenburg Ecclesiastical Consistory Kh. Goverdovsky informed of 27 nuns and 132 novices in 1916. There was a parochial school and an orphanage for orphaned girls at the monsatery" [22, p. 6]. On the territory of the monastery, there were two churches: one of them - in the name of the Holy Trinity, and the other one - in the name of Nicholas of Myra [23].
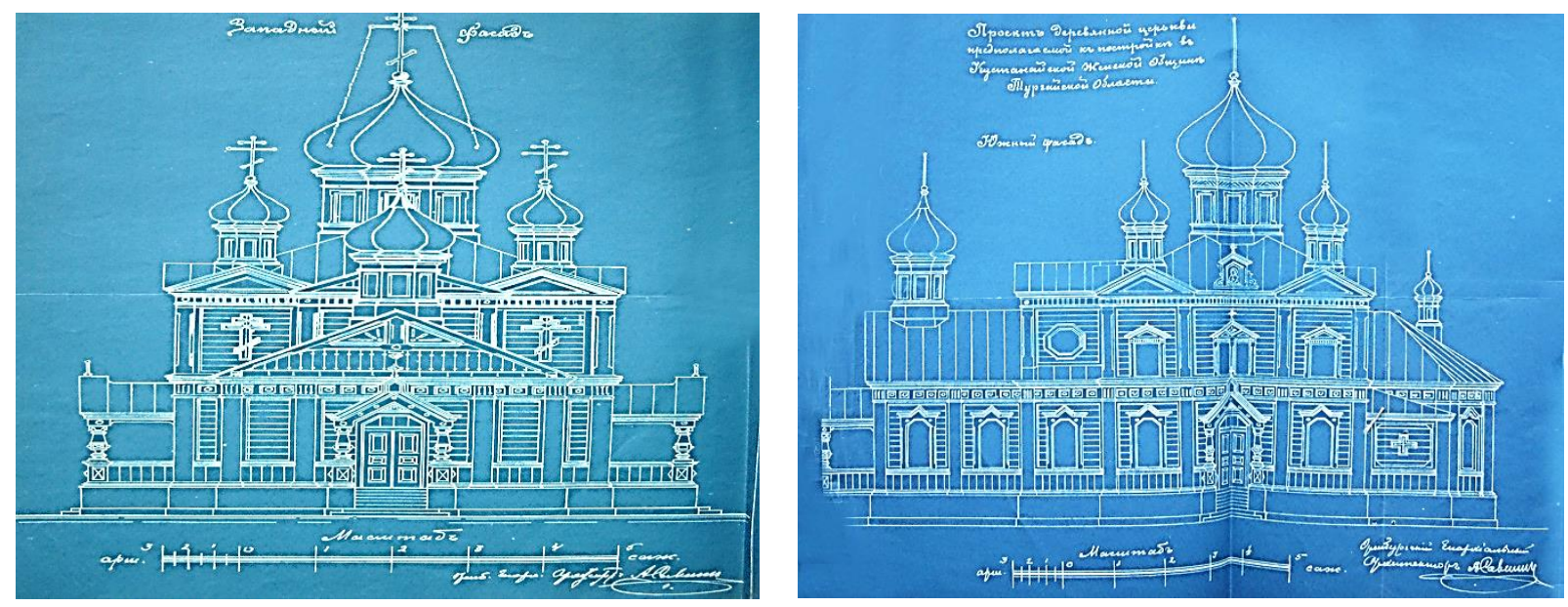

Photo 3. Design drawings of a wooden church in the Kostanay female community of Turgay region [24]

Conclusions. In this way, we could describe "church construction" on the territory of Kostanay city, the notion, which broadly speaking includes building of churches, church government, and administrative organization.

Thus, we can sum it up as follows:

- The active migration policy of the Russian Empire on the territory of Kazakhstan, especially in its northern regions, as well as the change in the Government's attitude to Islam having resulted in various measures of its containment, contributed to the fact that in the late $19^{\text {th }}-$ early $20^{\text {th }}$ centuries, Orthodoxy in Kazakhstan became widespread.

- The closest reasons for the establishment of dioceses were the following: this region contained within its borders a large foreign and non-Orthodox element, which at that time exceeded the number of the Orthodox population, which could have a bad effect on their religious feelings. At the same time, it was the presence of such an environment that predetermined the development of missionary work in the region.

- The migration of the population constantly updated the church construction. The immigrants, being bearers of the socio-cultural experience of the former homeland, took over the features of the new places of life. The vast majority of churches were built with funds raised by parishioners. 
- According to the pre-revolutionary tradition, all Orthodox churches can be divided according to the "departmental principle", i.e. according to who they are owned by. There are monastic temples, farmsteads, parishes, cemetery emples, house churches, court churches, churches attached to state institutions, educational institutions, military departments, charitable and spiritualeducational societies, etc. Churches, depending on their affiliation, have their own characteristics in the internal and especially external solution of the building. This is due to the significant features in the functioning of various types of churches. Thus, in the city of Kostanay there was a cathedral, a Refectory church and a monastic Orthodox temple in honor of the Iveron Icon of the Mother of God at the Kustanay female community, a cemetery church, while the rest of the city churches were parochial ones.

- From the compositional and spatial perspective, the investigated churches have: one(Constantino-Yeleninsk, Cemetery, etc.) or five-domed tops over the prayer hall (Nikolsk Cathedral and Michael Archangel Church); the main drum is covered with a dome (Nikolsk Cathedral) or a tent (Michael Archangel, Constantino-Yeleninsk, etc.); the bell tower is covered with a tent in all churches.

- The following styles are discernible in the temple architecture of Kostanay: provincial Baroque expressed in the use of individual expressive techniques, and along with an eclectic combination of classicism elements, motifs of national Russian style are used in combination with the techniques of the "brick" style.

- Construction of Orthodox temples led to irreversible positive changes in urban life. The Russian Orthodox Church had a great influence on all spheres, first and foremost, on education. Parochial schools and colleges were founded, and reading rooms were built at them. One of the important moral and educational functions of the church was considered to be battle against drunkenness and assistance to the penitentiary system.

This research is funded by the Science Committee of the Ministry of Education and Science of the Republic of Kazakhstan (Grant No. AP08857378)

\section{Литература}

1. Вебер М. Избранное. Образ общества. М.: Юрист, 1994. 704 с.

2. Феоктистова Е.А. Эволюция градостроительной культуры современного Казахстана (XVIII до н.э. - XXI в.н.э.). Автореферат диссертации на соискание уч. ст. канд. архитектуры. Екатеринбург, 2011. 27 с.

3. Попова 3.В. Православное зодчество городов Северо-Восточного Казахстана (XVIII начало XXI вв.): Авторефе. дисс. ... канд. архитектуры. Новосибирск, 2007. 27 с.

4. Михнова П.В. Среда и архитектурно-художественная система исторических городов Северо-Восточного Казахстана (начало XVIII - начало XXI вв.): Автореф. дисс. ... канд. архитектуры. Новосибирск, 2007. 27 с. 
5. Протоиерей Александр Берташ. Русское храмостроительство середины XIX - начала XX вв. В оценке дореволюционных и советских историков архитектуры: к историографии вопроса // Христианские чтения. Серия историческая. 2017. №5. С. 184-197.

6. Сарсембаева Г.А. Особенности формирования городского пространства Восточного Казахстана в XIX - начале XX века (на примере городов Семипалатинск и УстьКаменогорск) // Вестник НГУ. Серия: История, филология. 2017. Т. 16. №1. С. 80-92.

7. Alpyspaeva G.A., Sayahimova Sh.N. The Role of the Merchant Class in the Development of the Provincial City of Akmolinsk (the second half of the XIX - the beginning of the $\mathrm{XX}^{\text {th }}$ centuries) // Bylye Gody. 2018. Vol. 48. Is. 2. P. 688-698.

8. Костанайская область: прошлое и настоящее. Под ред. И.К. Тернового. Костанай, 2003. Ч.1. 409 c.

9. Обзор Тургайской области за 1899 г. Оренбург, 1901. Ведомость № 6.

10. Первая всеобщая перепись населения Российской империи 1897 г. Акмолинская область. Л. IX.

11. Из истории г. Костаная. Сборник документов и материалов. Костанай, 2009. 720 с.

12. Кустанай-Костанай. Очерки истории до 1936 г. Костанай, 2012. 608 с.

13. Кустанайский уезд 1917-1919. Сборник документов. Костанай, 2003. 154 с.

14. Кустанай: вчера, сегодня, завтра. Под ред. А.С. Елагина. Алма-Ата: Казахстан, 1979. $248 \mathrm{c}$.

15. Центральный государственный архив Республики Казахстан (далее - ЦГА РК). Ф.25. Оп.1. Д.3571. Л.1 об.-2; Костанайский областной историко-краеведческий музей. Отдел ХХ. Инвентарный номер 4164.

16. Духин Я.К. В зеркале истории - Кустанайский собор: жизнь и судьба // Кустанайские новости. 1993, 18 июня. С. 6.

17. Костанайская область: прошлое и настоящее. Под ред. И.К. Тернового. Костанай, 2003. Ч. 1.409 c.

18. Костанайский областной историко-краеведческий музей. Отдел ХХ. Инвентарный номер 4160, 4161.

19. Государственный архив Костанайской области. Ф.1031. Оп.2. Д.126. Л.139.

20. Королева Е.Д. Церковно-общественная жизнь православного населения Оренбургской губернии во второй половине XIX - начале XX вв. Автореф. дисс. ... канд. ист. наук. Челябинск, 2007. 27 с.

21. Конюченко А.И. Основные этапы и черты динамики монастырского строительства на Урале (дореволюционный период) // Религиозное многообразие Уральского региона. Материалы Всероссийской научно-практической конференции. Оренбург, 2014. С.48-65.

22. Духин Я.К. И стоял в Костанае монастырь... // Костанайские новости. 1997. 11 ноября. С. 6.

23. Тихановский А. Женский Иверский // Костанайские новости. 2004, 2 ноября. С. 5.

24. ЦГА РК Ф.25. Оп.1. Д.4842. Л.1 об. 2. 


\section{References}

1. Veber, M. (1994). Izbrannoe. Obraz obshchestva. Moscow. (In Russian).

2. Feoktistova, E.A. (2011). Evolyutsiya gradostroitel'noi kul'tury sovremennogo Kazakhstana (XVIII do n.e. - XXI v.n.e.). Avtoreferat dissertatsii na soiskanie uch. st. kand. arkhitektury. Ekaterinburg. (In Russian).

3. Popova, Z.V. (2007). Pravoslavnoe zodchestvo gorodov Severo-Vostochnogo Kazakhstana (XVIII - nachalo XXI vv.): Avtorefe. diss. ... kand. arkhitektury. Novosibirsk. (In Russian).

4. Mikhnova, P.V. (2007). Sreda i arkhitekturno-khudozhestvennaya sistema istoricheskikh gorodov Severo-Vostochnogo Kazakhstana (nachalo XVIII - nachalo XXI vv.): Avtoref. diss. ... kand. arkhitektury. Novosibirsk. (In Russian).

5. Protoierei Aleksandr, Bertash. (2017). Russkoe khramostroitel'stvo serediny XIX - nachala XX vv. V otsenke dorevolyutsionnykh i sovetskikh istorikov arkhitektury: k istoriografii voprosa. Khristianskie chteniya. Seriya istoricheskaya, (5), 184-197. (In Russian).

6. Sarsembaeva, G.A. (2017). Osobennosti formirovaniya gorodskogo prostranstva Vostochnogo Kazakhstana v XIX - nachale XX veka (na primere gorodov Semipalatinsk i Ust'Kamenogorsk). Vestnik NGU. Seriya: Istoriya, filologiya, 16(1), 80-92. (In Russian).

7. Alpyspaeva, G.A., \& Sayahimova, Sh.N. (2018). The Role of the Merchant Class in the Development of the Provincial City of Akmolinsk (the second half of the XIX - the beginning of the XXth centuries). Bylye Gody, 48(2), 688-698. (In Russian).

8. Kostană̌skaya oblast': proshloe i nastoyashchee (2003). Kostanai, 1. (In Russian).

9. Obzor Turgaiskoi oblasti za 1899 g. 1901. Orenburg, Vedomost'.

10. Pervaya vseobshchaya perepis' naseleniya Rossiiskoi imperii 1897 g. Akmolinskaya oblast'. L. IX. (In Russian).

11. Iz istorii g. Kostanaya (2009). Sbornik dokumentov i materialov. Kostanai.

12. Kustană-Kostanaĭ (2012). Ocherki istorii do 1936 g. Kostanai.

13. Kustanaĭskiǐ uezd 1917-1919. (2003). Sbornik dokumentov. Kostanai.

14. Kustanai: vchera, segodnya, zavtra (1979). Alma-Ata.

15. Tsentral'nyi gosudarstvennyi arkhiv Respubliki Kazakhstan (dalee - TsGA RK). F.25. Op.1. D.3571. L.1 ob.-2; Kostanaiskii oblastnoi istoriko-kraevedcheskii muzei. Otdel KhKh. Inventarnyi nomer 4164. (In Russian).

16. Dukhin, Ya.K. (1993). V zerkale istorii - Kustanaiskii sobor: zhizn' i sud'ba. Kustanaiskie

17. Kostanaǐskaya oblast': proshloe i nastoyashchee (2003). Kostanai.

18. Kostanaiskii oblastnoi istoriko-kraevedcheskii muzei. Otdel KhKh. Inventarnyi nomer 4160, 4161 .

19. Gosudarstvennyi arkhiv Kostanaiskoi oblasti. F.1031. Op.2. D.126. L.139.

20. Koroleva, E.D. (2007). Tserkovno-obshchestvennaya zhizn' pravoslavnogo naseleniya Orenburgskoi gubernii vo vtoroi polovine XIX - nachale XX vv. Avtoref. diss. ... kand. ist. nauk. Chelyabinsk. (In Russian). 
21. Konyuchenko, A.I. (2014). Osnovnye etapy i cherty dinamiki monastyrskogo stroitel'stva na Urale (dorevolyutsionnyi period). In Religioznoe mnogoobrazie Ural'skogo regiona. Materialy Vserossiiskoi nauchno-prakticheskoi konferentsii. Orenburg, 48-65. (In Russian).

22. Dukhin, Ya.K. (1997). I stoyal v Kostanae monastyr'... In Kostanaiskie novosti. 11 noyabrya. (In Russian).

23. Tikhanovskii, A. (2004). Zhenskii Iverskii. In Kostanaiskie novosti. 2004, 2 noyabrya.

24. TsGA RK F.25. Op.1. D.4842. L.1 ob. 2. (In Russian).

Nurbayev Zh.Ye., Nurbayeva S.B. Urban Realm and Temple Construction of the Russian Orthodox Church on the Cusp of 19th and 20th Centuries (Based on Photographic Documents of Kostanay City) // Вестник Нижневартовского государственного университета. 2021. № $3(55) . \quad$ C. 34-46. https://doi.org/10.36906/2311-4444/21-3/04

Nurbayev, Zh.Ye. \& Nurbayeva, S.B. (2021). Urban Realm and Temple Construction of the Russian Orthodox Church on the Cusp of 19th and 20th Centuries (Based on Photographic Documents of Kostanay City). Bulletin of Nizhnevartovsk State University. (3(55)). 34-46. (In Russian). https://doi.org/10.36906/2311-4444/21-3/04 